\title{
Ketidaktercapaian Bonus Demografi: Pembelajaran dari Sumatera Barat
}

\author{
Dian Sri Andriani ${ }^{1}$, Agus Joko Pitoyo², dan Evita Hanie Pangaribowo² \\ ${ }^{1}$ Program Studi Kependudukan, Sekolah Pascasarjana, Universitas Gadjah Mada, \\ Yogyakarta, ${ }^{2}$ Fakultas Geografi, Universitas Gadjah Mada, Yogyakarta \\ Korespondensi: Dian Sri Andriani (e-mail: diansriandriani.25@gmail.com)
}

\begin{abstract}
Abstrak
Indonesia telah memasuki fase bonus demografi sejak tahun 2012 ketika beban ketergantungan penduduk berada di bawah 50 per 100 penduduk produktif. Namun, berdasarkan proyeksi beban ketergantungan penduduk tahun 2010-2035 tidak semua provinsi di Indonesia akan meraih bonus demografi, salah satunya adalah Provinsi Sumatera Barat. Besarnya beban ketergantungan penduduk Sumatera Barat tercermin dari pergeseran struktur umur penduduk yang dipengaruhi oleh dinamika demografi yang berlangsung dari beberapa dekade sebelumnya. Tulisan ini akan menguraikan secara time series berlangsungnya ketiga komponen demografi di Sumatera Barat. Tren mortalitas bayi dan anak mengalami penurunan, bahkan pada 2012 telah mengindikasikan berada di akhir masa transisi demografi. Namun, penurunan mortalitas tersebut tidak diiringi dengan penurunan fertilitas yang signifikan. Tingkat fertilitas yang masih tinggi menjadi penyumbang bertambahnya beban ketergantungan penduduk muda. Kondisi tersebut diperparah dengan angka migrasi neto yang konsisten minus di setiap periode sehingga proporsi penduduk umur produktif tidak mengalami penambahan yang signifikan.
\end{abstract}

Kata kunci: bonus demografi, beban ketergantungan, mortalitas, fertilitas, migrasi

\section{Bonus Demography Not Achieved: Learning from West Sumatera}

\begin{abstract}
Indonesia has entered a demographic dividend in 2012 since the dependency ratio of population was below 50 per 100 of productive population. However, based on the projection of dependency ratio in 2010-2035, not all provinces in Indonesia will reach the demographic dividend, one of them is West Sumatera Province. The high dependency ratio of West Sumatera is reflected in a shift of population age structure influenced by the demographic dynamics that lasted from the previous few decades. This paper will describe the time series on three demographic components in West Sumatera. Infant and child mortality trends have decreased and in 2012 it was indicated to be at the end of the demographic transition period. However, the decrease in mortality is not accompanied by a significant decline in fertility. The high fertility rate contributes to the rising of dependency ratio to young population. The condition is worsened by net migration rate which is consistently minus in each period, thus the proportion of the productive population does not increase significantly.
\end{abstract}

Keywords: demographic dividend, dependency ratio, mortality, fertility, migration 


\section{Pendahuluan}

Indonesia tahun 2017, menurut CIA World Factbook, merupakan negara dengan jumlah penduduk terbanyak urutan keempat di dunia, yaitu 260.580.739 jiwa atau 3,51 persen dari total penduduk dunia. Besarnya jumlah penduduk ini akan memengaruhi struktur umur penduduk, baik distribusi maupun komposisi penduduk. Dinamika struktur umur penduduk disebabkan oleh berlangsungnya proses demografi, meliputi fertilitas, mortalitas, dan migrasi penduduk yang saling berpengaruh satu sama lain.

Transisi demografi sebagai proses awal telah menggambarkan terjadinya dinamika struktur umur penduduk yang ditandai dengan menurunnya mortalitas dan fertilitas. Bloom, et.al. (2011) mendeskripsikan transisi demografi sebagai transisi menurunnya angka mortalitas dan fertilitas, dengan penurunan mortalitas mendahului penurunan fertilitas sebagai akibat dari kemajuan ilmu dan teknologi di bidang kesehatan. Struktur umur penduduk Indonesia juga telah mengalami proses transisi demografi.

Ananta (1997) menguraikan bahwa transisi demografi telah terjadi tahun 1950-an saat penurunan mortalitas yang cepat sehingga turut memengaruhi perubahan jumlah, komposisi, dan pertumbuhan penduduk Indonesia yang cepat pula. Pada 1997-an terjadi penurunan fertilitas sehingga angka pertumbuhan penduduk periode 1980 sampai 1990-an juga menurun dengan cepat.

Transisi demografi tersebut telah mengantarkan Indonesia pada proses demografi selanjutnya yang dikenal dengan bonus demografi. Berbagai literatur studi kependudukan menggunakan istilah bonus demografi untuk menggambarkan keuntungan ekonomis yang diterima oleh suatu daerah atau negara akibat menurunnya rasio ketergantungan (dependency ratio), yaitu besarnya jumlah penduduk umur produktif (15-64 tahun) dibandingkan dengan penduduk non produktif (0-14 tahun dan 65 tahun ke atas). Suatu daerah dianggap dapat menikmati bonus demografi apabila dependency ratio berada di bawah angka 50 .

Bonus demografi di Indonesia telah dimulai sejak tahun 2012, yaitu ketika dependency ratio Indonesia berada di bawah angka 50 dan akan mencapai titik terendah tahun 20282031 (Kominfo, 2014). Hal itu berarti bahwa penduduk umur produktif berjumlah dua kali lipat dibandingkan dengan penduduk yang bukan umur produktif. Namun, proses transisi demografi di Indonesia tidak serta-merta menunjukkan adanya perjalanan yang sama untuk setiap provinsi. Akibatnya, tidak semua provinsi akan menerima bonus demografi. Berdasarkan hasil proyeksi penduduk tahun 2010-2035, terdapat beberapa provinsi yang belum akan menerima bonus demografi hingga tahun 2035, salah satunya adalah Sumatera Barat. Hal ini disebabkan oleh dependency ratio Sumatera Barat yang masih tinggi.

Dependency ratio Sumatera Barat tahun 2010 adalah 57,7 per 100 penduduk produktif, sedangkan Indonesia telah menempati angka 50,5 tahun yang sama. Dependency ratio Sumatera Barat pun diproyeksikan belum akan menyentuh angka 50 hingga tahun 2035, padahal suatu daerah dikatakan dapat menikmati bonus demografi apabila dependency ratio berada di bawah angka 50 . Kominfo (2014) berasumsi bahwa penyebab Provinsi Sumatera Barat tidak dapat memasuki fase bonus demografi karena adanya tradisi merantau (migrasi keluar) oleh masyarakat setempat, terutama bagi penduduk usia produktif. Namun, dinamika 
pertumbuhan penduduk di suatu daerah tidak hanya dipengaruhi oleh migrasi, tetapi juga oleh fertilitas dan mortalitas sebagai kesatuan komponen yang memengaruhi berlangsungnya proses demografi. Pencapaian dependency ratio saat ini merupakan hasil dari perjalanan proses demografi beberapa dekade sebelumnya.

Secara demografis, apabila mortalitas mengalami penurunan, maka pengaruh yang diberikan dapat dilihat dari meningkatnya jumlah bayi hidup yang sekaligus akan menambah jumlah penduduk usia produktif di masa mendatang. Sementara itu, fertilitas memberikan dampak positif apabila mengalami penurunan karena dapat mengurangi proporsi penduduk muda dan dependency ratio penduduk muda (0-14 tahun). Dewasa ini proses transisi demografi juga sangat dipengaruhi oleh migrasi penduduk sebagai variabel penambah atau pengurang jumlah penduduk di suatu daerah.

Fenomena migrasi di Sumatera Barat diwarnai oleh tradisi merantau dan dapat disaksikan bahwa saat ini banyak orang Minangkabau tersebar di pulau-pulau di Indonesia. Naim (2013) mengemukakan bahwa karakteristik migran keluar (perantau) pada umumnya adalah penduduk usia produktif, yaitu rentang usia 15 sampai 64 tahun. Asumsinya adalah banyaknya penduduk produktif yang bermigrasi keluar daerah menyebabkan proporsi penduduk produktif berkurang dan nantinya berdampak pada tingginya dependency ratio.

Olehkarenaitu, tulisan iniakanmemaparkan berlangsungnya ketiga komponen demografi di Sumatera Barat secara time series guna mengetahui pengaruh yang diberikan terhadap perubahan struktur umur penduduk yang mengakibatkan Sumatera Barat tidak dapat meraih bonus demografi.

\section{Metode Penelitian}

Jenis penelitian ini adalah deskriptif berbasis analisis data sekunder secara runtut waktu (time series). Adapun langkah yang perlu dilakukan dalam proses penelitian menggunakan analisis data sekunder adalah merumuskan masalah, menentukan unit analisis, memeriksa kembali ketersediaan data, melakukanstudipustaka, mengumpulkan data, mengolah data sekunder, menyajikan data serta memberikan interpretasi, dan menyusun laporan hasil penelitian (Martono, 2010). Penelitian ini menggunakan data publikasi dari Badan Pusat Statistik (BPS), meliputi Sensus Penduduk tahun 1971-2010, SDKI tahun 1994-2012, dan SUPAS tahun 1985-2015.

Adapun data yang akan dianalisis adalah 1) mortalitas berupa mortalitas bayi (Infant Mortality Rate/IMR) dan mortalitas anak (Child Mortality Rate/CMR); 2) fertilitas berupa Total Fertility Rate (TFR); serta 3) migrasi penduduk berupa migrasi neto risen. Analisis antarvariabel dilakukan dengan pendekatan secara historis (historycal perspective). Informasi hasil analisis data disajikan dalam bentuk tulisan atau uraian, tabel, dan diagram. Hasil analisis juga diperkuat dengan studi literatur, seperti temuan sebelumnya berupa jurnal yang telah dipublikasi dan laporan ilmiah yang relevan dengan topik penelitian ini.

\section{Pembahasan}

Bonus demografi merupakan fase lanjutan dari berlangsungnya transisi demografi. Suatu daerah berpotensi atau tidak berpotensi meraih bonus demografi dapat dilihat dari struktur umur penduduk yang memengaruhi tinggi rendahnya dependency 
Dian Sri Andriani, Agus Joko Pitoyo, dan Evita Hanie Pangaribowo

Tabel 1. Dependency Ratio Provinsi Sumatera Barat Tahun 1971-2015

\begin{tabular}{lrrrrrr}
\hline \multirow{2}{*}{ Kelompok Umur } & \multicolumn{7}{c}{ Tahun } \\
\cline { 2 - 7 } & \multicolumn{1}{c}{$\mathbf{1 9 7 1}$} & $\mathbf{1 9 8 0}$ & $\mathbf{1 9 9 0}$ & $\mathbf{2 0 0 0}$ & $\mathbf{2 0 1 0}$ & \multicolumn{1}{c}{$\mathbf{2 0 1 5}$} \\
\hline 0-14 tahun & 1.260 .390 & 1.445 .473 & 1.570 .291 & 1.429 .321 & 1.547 .051 & 1.585 .231 \\
15-64 tahun & 1.401 .535 & 1.767 .858 & 2.220 .290 & 2.561 .056 & 3.025 .126 & 3.330 .651 \\
65 tahun ke atas & 113.171 & 143.777 & 164.779 & 204.521 & 274.732 & 274.695 \\
$\begin{array}{l}\text { Youth Dependency } \\
\text { Ratio }\end{array}$ & 89,93 & 81,76 & 70,72 & 55,81 & 51,14 & 47,60 \\
$\begin{array}{l}\text { Aged Dependency } \\
\text { Ratio }\end{array}$ & 8,07 & 8,13 & 7,42 & 7,99 & 9,08 & 8,25 \\
$\begin{array}{l}\text { Total Dependency } \\
\text { Ratio }\end{array}$ & $\mathbf{9 8 , 0 0}$ & $\mathbf{8 9 , 9 0}$ & $\mathbf{7 8 , 1 5}$ & $\mathbf{6 3 , 8 0}$ & $\mathbf{6 0 , 2 2}$ & $\mathbf{5 5 , 8 4}$ \\
\hline
\end{tabular}

Sumber: Diolah berdasarkan data Sensus Penduduk (1971, 1980, 1990, 2000, 2010) dan SUPAS (2015)

ratio sebagai parameter memasuki fase bonus demografi. Adapun dependency ratio penduduk Sumatera Barat dapat dilihat pada Tabel 1.

Pada Tabel 1 dapat dilihat bahwa dari tahun 1971 sampai tahun 2015, dependency ratio penduduk Sumatera Barat telah mengalami penurunan, tetapi masih berada di atas angka 50 yang mengindikasikan bahwa hingga tahun 2015 Sumatera Barat dikategorikan tidak akan memasuki fase bonus demografi. Besarnya dependency ratio masih disebabkan oleh besarnya jumlah penduduk muda yang menjadi tanggungan. Kondisi tersebut juga memperlihatkan bahwa struktur umur penduduk Sumatera Barat masih tergolong muda. Dinamika struktur umur penduduk lebih mudah dipahami apabila disajikan dalam bentuk piramida penduduk. Secara time series, berikut ini akan disajikan piramida penduduk Sumatera Barat dari tahun 1971 hingga tahun 2015.

Piramida penduduk pada Gambar 1 memperlihatkan bahwa dari tahun 1971 hingga tahun 2000, struktur umur penduduk Sumatera Barat telah mengalami perubahan yang cukup signifikan meskipun piramida penduduknya masih bertipe ekspansif atau dikategorikan muda. Tren dinamika demografi sebagaimana yang terlihat pada piramida penduduk telah menunjukkan adanya penurunan proporsi penduduk muda (0-14 tahun). Piramida penduduk tahun 2010 hingga tahun 2015 menunjukkan bahwa Sumatera Barat dapat dikatakan meninggalkan struktur umur penduduk muda. Kondisi tersebut dapat dikategorikan masuk pada tahap intermediate, yaitu kondisi struktur umur penduduk yang masih mempunyai ciri agak ekspansif dan telah menunjukkan kecenderungan ke tahap konstruktif (Asmanedi dan Wiyono, 2007). Hal ini ditandai dengan masih melebarnya bagian dasar piramida penduduk (penduduk muda), mulai bertambahnya bagian tengah piramida (penduduk produktif), dan mulai melebarnya bagian atas piramida (bertambahnya penduduk usia lanjut). Perubahan struktur umur penduduk Sumatera Barat tersebut 
Ketidaktercapaian Bonus Demografi:

Pembelajaran dari Sumatera Barat

Piramida Penduduk Sumatera Barat Tahun 1971

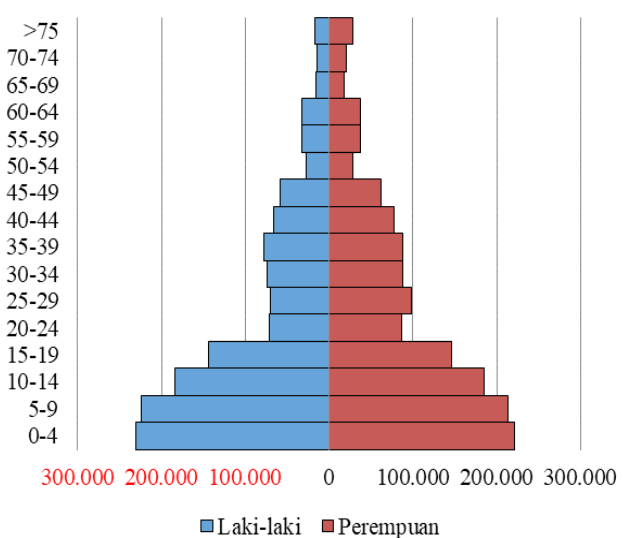

Piramida Penduduk Sumatera Barat Tahun 1990

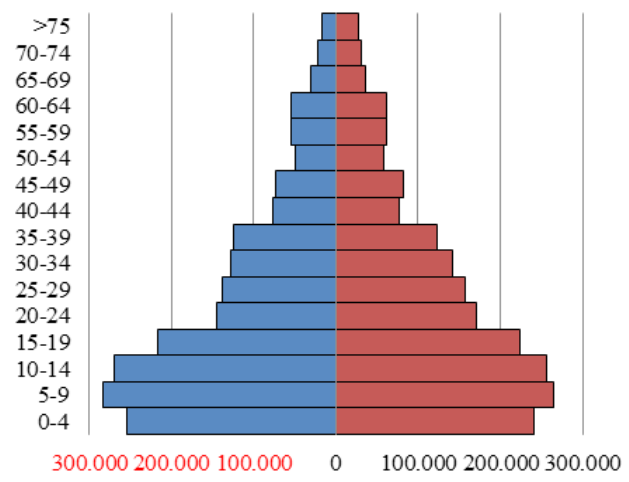

口Laki-laki $\quad$ Perempuan

Piramida Penduduk Sumatera Barat Tahun 2010

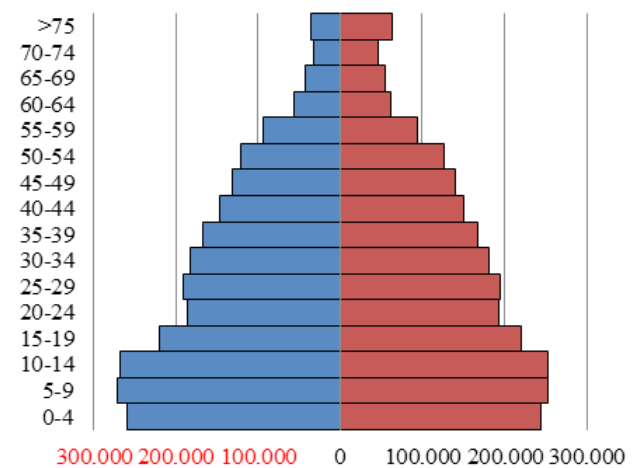

口Laki-laki $\quad$ Perempuan
Piramida Penduduk Sumatera Barat Tahun 1980

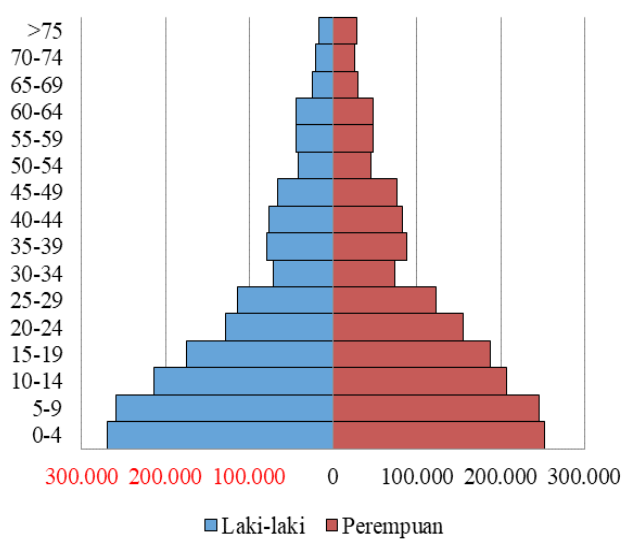

Piramida Penduduk Sumatera Barat Tahun 2000

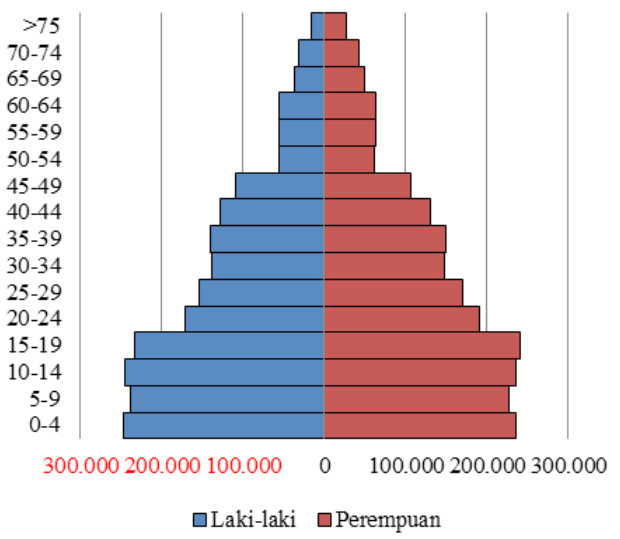

Piramida Penduduk Sumatera Barat Tahun 2015

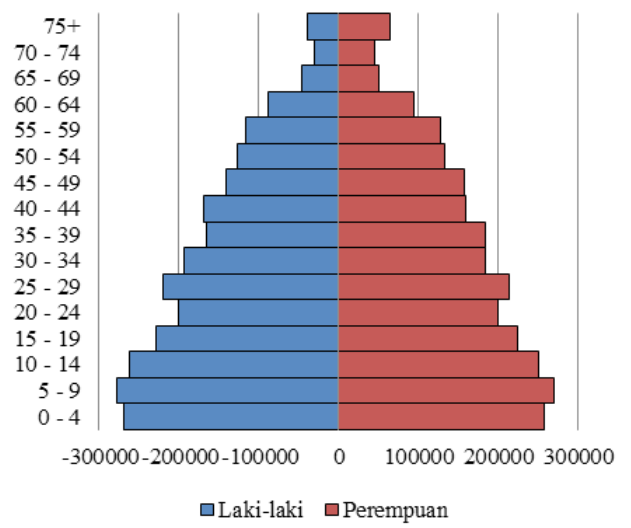

Sumber: Diolah berdasarkan data Sensus Penduduk (1971, 1980, 1990, 2000, 2010) dan SUPAS (2015)

Gambar 1 Piramida Penduduk Sumatera Barat Tahun 1971-2015 
merupakan akibat berlangsungnya proses demografi dari beberapa waktu silam, meliputi mortalitas, fertilitas, dan migrasi penduduk. Berikut adalah detail ketiga hal tersebut.

\section{Mortalitas}

Parameter mortalitas yang digunakan untuk melihat dinamika proporsi penduduk muda adalah IMR dan CMR. Hal ini berkenaan dengan struktur umur penduduk muda yang masih tergolong relatif muda sehingga untuk kajian bonus demografi ini, penurunan dependency ratio lebih disumbangkan oleh banyaknya penurunan penduduk muda (youth dependency ratio) dibandingkan dengan penduduk tua (elderly dependency ratio).

Sumatera Barat merupakan salah satu provinsi yang berkontribusi tinggi dalam IMR dan CMR. BPS (2010) menggolongkan Sumatera Barat sebagai satu dari deretan provinsi lainnya (Bengkulu, Kalimantan Selatan, Sulawesi Tengah, Sulawesi Tenggara, dan Maluku) di Indonesia yang memiliki IMR di atas rata-rata nasional kurun waktu 1971-2010. Tren IMR dan CMR Sumatera Barat secara grafis dapat diamati pada Gambar 2 dan 3.

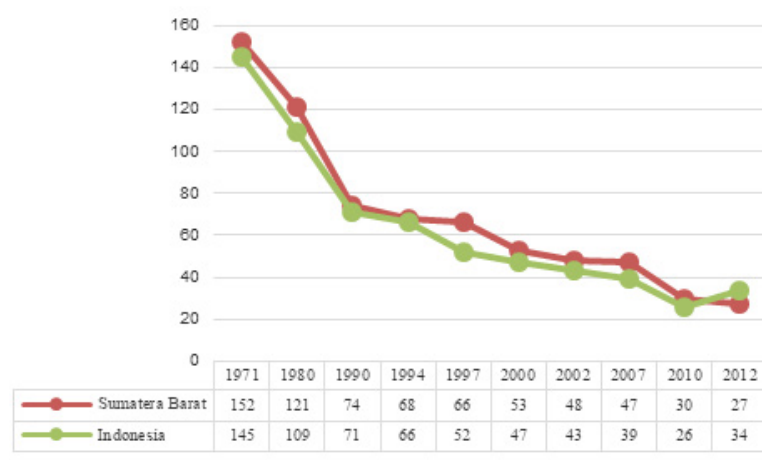

Grafik pada Gambar 2 dan 3 memperlihatkan bahwa IMR dan CMR di Sumatera Barat tahun 1971 sangat tinggi. Kondisi tersebut juga terjadi secara nasional karena diketahui bahwa IMR dan CMR Indonesia berturut-turut sebesar 145 per 1.000 kelahiran hidup dan 218 per 1.000 kelahiran hidup. Mantra (2013) menjelaskan bahwa tingginya IMR saat itu disebabkan oleh kondisi masyarakat yang berkaitan dengan pembangunan, mengingat Indonesia pasca kemerdekaan baru mulai melakukan perbaikan di berbagai bidang. Tidak stabilnya produksi pangan dan susu turut menyumbang mortalitas bayi dan anak pada saat itu. Produksi pangan tahun 1960-an tidak dapat mengimbangi tingkat pertambahan penduduk dan tidak terdistribusi secara merata. Pada tahun 1966, produksi susu turun drastis karena berakhirnya program sumbangan susu dari UNICEF. Dampaknya, penyakit anak menjadi penyebab kematian yang penting pada saat itu. Selain itu, terjadi pula kenaikan harga pangan sehingga konsumsi pangan dan nutrisi menurun. Di samping fluktuasi masalah persediaan pangan, kemajuan di bidang kesehatan pun tidak menentu, terlebih

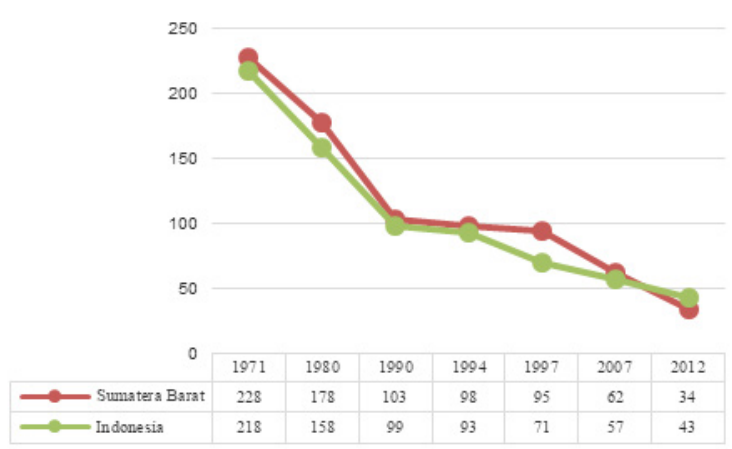

Sumber: Diolah berdasarkan data Sensus Penduduk (1971, 1980, 1990) dan SDKI (1994, $1997,2007,2012)$

Gambar 2 Tren IMR Sumatera Barat dan Indonesia Tahun 1971-2012
Gambar 3 Tren CMR Sumatera Barat dan Indonesia Tahun 1971-2012 
saat laju inflasi semakin meningkat. Fasilitas kesehatan yang tidak memadai berperan penting sebagai kontributor kenaikan IMR (Bloom dan Canning, 2011).

Parameter IMR dan CMR ini merupakan tolak ukur yang sensitif dari semua upaya intervensi yang dilakukan oleh pemerintah, khususnya di bidang kesehatan (Siswono, 2015) sehingga seiring dengan perkembangan teknologi yang semakin maju serta peningkatan pelayanan kesehatan, IMR terus mengalami penurunan. Hal ini juga dialami di Sumatera Barat. Data menunjukkan bahwa IMR menurun secara signifikan sesuai dengan gambaran indikasi awal terjadinya transisi demografi. Penurunan terbesar terjadi dalam dua dekade, yaitu tahun 1971 dari 152 menurun ke angka 121 tahun 1980 dan turun menjadi 74 tahun 1990. Selama dua dekade tersebut, Sumatera Barat telah mampu menurunkan IMR sebesar 48,68 persen. Begitu juga dengan CMR Sumatera Barat yang turut mengalami penurunan secara drastis sebesar 45,17 persen dalam kurun waktu 1971 hingga 1990. Kondisi penurunan IMR dan CMR yang drastis selama dua dekade di Sumatera Barat sama halnya dengan yang terjadi di tingkat nasional. Hal ini disebabkan oleh telah dimulainya rencana pembangunan lima tahun (Repelita) pertama dan berkurangnya inflasi sesudah tahun 1968 sehingga terjadi perbaikan-perbaikan di bidang kesehatan masyarakat. Puskesmas mulai didirikan di kota-kota kecamatan serta tenaga dokter, perawat, dan bidan mulai dimobilisasi di pusat-pusat kesehatan sehingga mulai tampak penurunan tingkat kematian di Indonesia (Mantra, 2013).

Kondisi pemerintahan yang sentralistik tersebut telah memengaruhi penurunan mortalitas bayi dan anak di berbagai provinsi di Indonesia, termasuk Sumatera Barat. Kemajuan penurunan IMR, baik skala nasional maupun tingkat provinsi hingga tahun 1990, dinilai sebagai akibat dari peningkatan kuantitas dan kualitas kesehatan dari tahuntahun sebelumnya. Penurunan IMR dan CMR di Sumatera Barat terus berlangsung hingga tahun 2010, bahkan lebih dari setengah kematian bayi dan anak tahun 1990 dapat ditekan dalam waktu 10 tahun. Angka mortalitas bayi dan anak di Sumatera Barat konsisten mengalami penurunan dari tahun 2010. Namun, penurunan tersebut relatif masih tinggi dibandingkan dengan provinsi lainnya dan rata-rata nasional. Tingginya IMR dan CMR disebabkan oleh belum meratanya sarana dan prasarana kesehatan serta rendahnya kesadaran masyarakat tentang pentingnya kesehatan ibu dan bayi (Alfana, et.al., 2015; UNICEF, 2012).

Pada tahun 2012 penurunan IMR Sumatera Barat telah berhasil melampaui IMR nasional, yaitu menjadi 27 per 1.000 kelahiran hidup, sedangkan Indonesia masih berada di angka 34 per 1.000 kelahiran hidup. Begitu juga dengan CMR Sumatera Barat tahun 2012 menurun ke angka 34 per 1.000 kelahiran hidup, sedangkan Indonesia masih berkisar 43 per 1.000 kelahiran hidup. Capaian penurunan IMR dan CMR tersebut berkaitan dengan kinerja pemerintah yang fokus di bidang kesehatan neonatal, bayi, dan penanggulangan penyakit pada anak yang telah berkontribusi positif terhadap penurunan mortalitas bayi di Sumatera Barat (Dinkes Sumbar, 2014). Sebagaimana yang diketahui bahwa indikator kematian berguna untuk memonitor kinerja pemerintah dalam meningkatkan kesejahteraan masyarakat, terutama di bidang kesehatan yang turut didukung oleh semakin majunya ilmu kedokteran (Wongboonsin dan Phiromswad, 2016). Hal ini dibuktikan dengan grafik yang selalu bergerak turun di setiap periodenya. 
Hasil SDKI tahun 2012 menunjukkan bahwa IMR dan CMR Sumatera Barat dibandingkan dengan provinsi lain di Indonesia telah memperlihatkan penurunan yang cukup signifikan. Data profil kesehatan Sumatera Barat mencatat telah terjadinya keberhasilan dalam peningkatan derajat kesehatan masyarakat yang dilihat dari IMR dan CMR, khususnya sebagai parameter yang berkontribusi dalam dinamika struktur umur penduduk muda. Sumatera Barat merupakan salah satu provinsi yang dinilai memiliki inovasi dalam kebijakan pembangunan kesehatan ibu dan anak (KIA) yang mampu secara signifikan menurunkan angka mortalitas bayi dan anak (Nurrizka dan Saputra, 2013).

Keberhasilan Sumatera Barat dalam menurunkan IMR hingga ke angka 27 per 1.000 kelahiran hidup tahun 2012 dan disertai dengan penurunan CMR yang turun hingga ke angka 34 per 1.000 kelahiran hidup telah mengantarkan provinsi ini mengakhiri masa transisi demografinya. Sebagaimana Ananta dan Arifin (2008) mengemukakan bahwa akhir transisi demografi di suatu daerah ditandai dengan IMR yang kurang dari 30 per 1.000 kelahiran hidup. Dampak yang diberikan oleh penurunan drastis IMR dan CMR adalah bertambahnya jumlah bayi yang akan tetap hidup sampai usia dewasa (Adioetomo dan Samosir, 2010).

\section{Fertilitas}

Awal transisi demografi diindikasikan dengan terjadinya penurunan mortalitas bayi dan anak secara drastis dan selanjutnya diikuti dengan penurunan fertilitas. Pada Gambar 4 dapat dilihat tren fertilitas Sumatera Barat dari tahun 1971 sampai tahun 2012.

Angka fertilitas Sumatera Barat tahun 1971 sebesar 6,18 , sedangkan nasional berada di angka 5,61. Fertilitas yang sangat tinggi tahun itu dapat dikaitkan dengan fenomena baby boom pasca kemerdekaan RI. Pada tahuntahun awal kemerdekaan fenomena baby boom belum memberikan pengaruh yang besar pada penambahan jumlah penduduk karena wilayah Indonesia yang masih sangat luas untuk dapat menampung penduduk saat itu. Namun, kondisi kelahiran yang tinggi ini terus berlangsung sehingga ledakan jumlah penduduk dari tahun ke tahun pun tidak dapat dielakkan. Efek dari fenomena

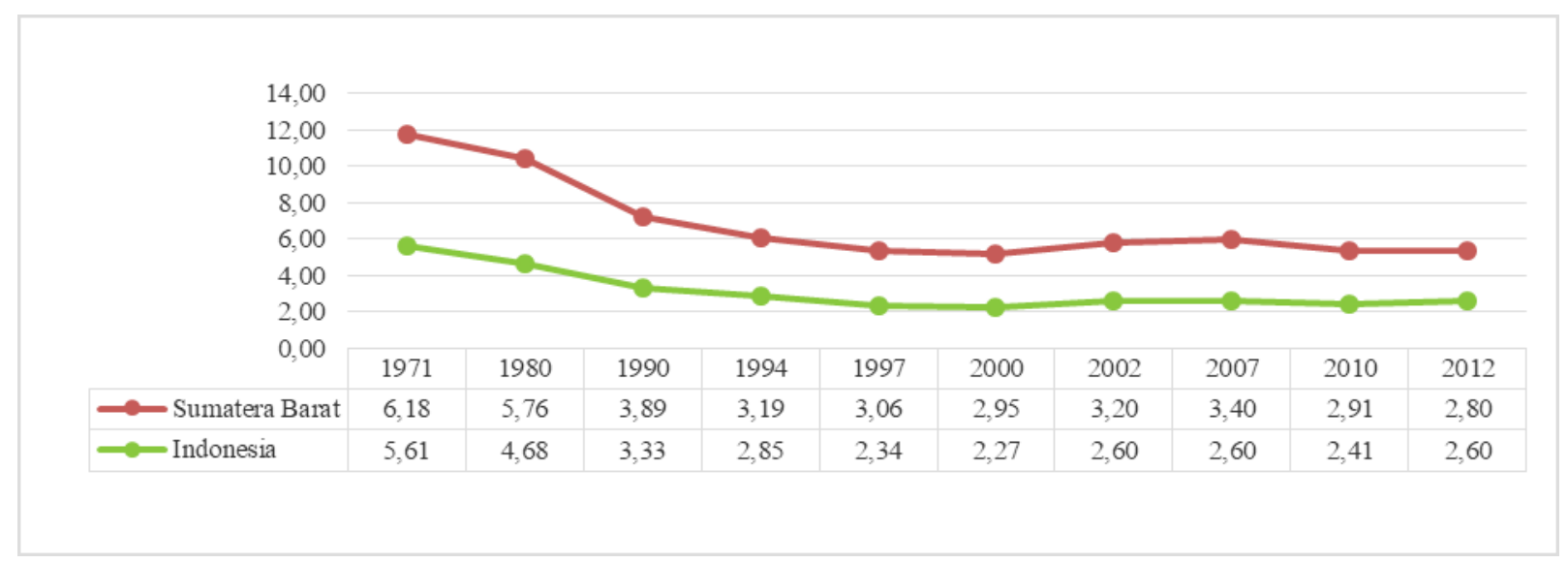

Sumber: Diolah berdasarkan data Sensus Penduduk (1971, 1980, 1990, 2000, 2010) dan SDKI (1991, 1994, 1997, 2002, 2007, 2012)

Gambar 4 Tren TFR Sumatera Barat dan Indonesia Tahun 1971-2012 
baby boom di awal kemerdekaan RI masih berlanjut hingga beberapa dekade berikutnya sehingga TFR tahun 1971 masih tinggi. Pada tahun 1971 TFR Sumatera Barat sebesar 6,18 yang dapat diartikan bahwa rata-rata perempuan usia subur di Sumatera Barat mempunyai anak sebanyak 6 orang. Angka ini melebihi TFR nasional untuk tahun yang sama, yaitu sejumlah 5,61. Namun, berkat adanya program KB di Indonesia yang mulai dicanangkan sejak tahun 1970-an, TFR mulai mengalami penurunan.

Keberhasilan Indonesia dalam menurunkan TFR dengan cepat di masa lalu berkaitan erat dengan berbagai faktor dan kebijakan, terutama kampanye program KB yang gencar mendidik masyarakat terkait pengaturan kelahiran (Hatmadji, et.al., 2010). Pelaksanaan program KB yang sentralistik telah memberikan pengaruh yang signifikan terhadap penurunan TFR hingga tingkat provinsi. Efek program KB juga terlihat dari penurunan TFR yang signifikan di Sumatera Barat, terutama tahun 1971 hingga tahun 1990. Kondisi TFR pada dua dekade ini sangat dipengaruhi oleh keberadaan Program KB dengan pelaksanaan yang otoriter di masa pemerintahan presiden kedua RI, yaitu Soeharto, dengan kebijakan kependudukan yang berubah dari pronatalis menjadi antinatalis (Salim, et.al., 2015; Mantra, 2013; Hatmadji, et.al., 2010). Ketatnya pelaksanaan KB hingga ke daerah-daerah merupakan upaya serius pemerintah merespons tingginya jumlah kelahiran agar dapat menurunkan sekaligus menekan angka kelahiran.

Pada tahun 1971 TFR Sumatera Barat sebesar 6,18 turun menjadi 5,61 tahun 1980 . Penurunan drastis terjadi tahun 1990 ke angka 3,89 meskipun masih berada di atas TFR nasional yang telah menyentuh angka 3,33 . Studi fertilitas yang dilakukan oleh Latif (1985) memperlihatkan bahwa penurunan
TFR hingga tahun 1980 yang masih tergolong tinggi di Sumatera Barat karena adanya situasi fertilitas alami (natural fertility) di awal kampanye program KB. Fertilitas perempuan usia subur di Sumatera Barat bersifat alami karena perencanaan program KB belum populer di masyarakat. Namun, penurunan yang signifikan di dua dekade tersebut mengindikasikan bahwa dilihat dari komponen fertilitasnya, Sumatera Barat telah mengalami masa transisi demografi yang sebelumnya pun telah diawali dengan penurunan mortalitas.

Pakar demografi menyatakan bahwa setelah mengalami penurunan TFR yang signifikan sebagai indikasi terjadinya transisi demografi, penurunan TFR selanjutnya akan cenderung melambat hingga menyentuh angka 2,1 untuk setiap perempuan usia subur di daerah tersebut. Hal ini juga terjadi di Sumatera Barat, setelah mengalami penurunan TFR yang cepat selama dua dekade, TFR di tahun-tahun berikutnya cenderung melambat. TFR Sumatera Barat tahun 1994 sebesar 3,19 per perempuan usia subur kemudian terus mengalami penurunan secara lambat ke angka 3,06 tahun 1997 dan 2,95 tahun 2000. Perubahan rezim tahun 1998 membuat dukungan kelembagaan untuk program KB melemah (Salim, et.al., 2015). Perubahan kebijakan BKKBN yang desentralisasi memperlihatkan adanya kecenderungan terjadi lagi peningkatan TFR di Indonesia (Noveria, 2011). Dampak dari desentralisasi BKKBN tersebut turut menyebabkan meningkatnya TFR di Sumatera Barat, yaitu tahun 2002 hingga tahun 2007 TFR meningkat dari 3,20 ke 3,40 per perempuan usia subur. Kenaikan juga terjadi di tingkat nasional menjadi 2,60 yang bahkan stagnan hingga tahun 2012.

Pada 2010 TFR Indonesia dan Sumatera Barat bersama-sama mengalami penurunan. TFR Indonesia turun ke angka 2,41 dan 
Sumatera Barat turun menjadi 2,91. TFR yang kembali mengalami penurunan merupakan suatu prestasi yang telah diraih oleh Sumatera Barat dan termasuk dalam lima besar provinsi di Indonesia yang mampu menurunkan TFR menjadi 2,80 per perempuan usia subur tahun 2012. Namun, apabila dibandingkan dengan TFR nasional, TFR Sumatera Barat masih tergolong tinggi. TFR Indonesia tahun 2012 telah mencapai angka 2,60 meskipun Indonesia dan Sumatera Barat sama-sama belum mampu mencapai target TFR sebesar 2,1 dalam rangka mewujudkan pertumbuhan penduduk stabil.

Studi fertilitas yang dilakukan oleh Iskarni (2012) di Sumatera Barat tahun 2010 memperlihatkan bahwa tingginya TFR disebabkan oleh meningkatnya penduduk usia subur sebesar 11 persen dari periode sensus penduduk sebelumnya, yaitu tahun 2000. Peningkatan tersebut memengaruhi jumlah pasangan usia subur yang mengalami peningkatan dan nantinya turut memengaruhi kenaikan jumlah pasangan yang bukan akseptor KB (unmet need) serta umur kawin pertama yang masih rendah. Angka fertilitas tertinggi banyak terdapat di daerah dengan kondisi geografis yang terpencil, tertinggal, perbatasan, pantai, dan kepulauan (gaciltas). Kondisi daerah yang sulit dijangkau mengakibatkan pelaksanaan program KB tidak efektif. Adanya faktor-faktor yang memengaruhi tingginya fertilitas di tingkat kabupaten/kota akan berkontribusi pada ratarata TFR provinsi.

Tren fertilitas Sumatera Barat menurun dari tahun 1971 sampai tahun 2012 meskipun masih tergolong tinggi dibandingkan dengan TFR nasional. Hal ini telah memengaruhi struktur umur penduduk Sumatera Barat yang dapat dilihat dari semakin berkurangnya bagian dasar piramida penduduk (lihat Gambar 1). Adapun jumlah penduduk 0-14 tahun (lihat
Tabel 1) yang terus bertambah merupakan kontribusi banyaknya perempuan usia subur kohor baby boom yang melahirkan anak. Proporsi penduduk muda di Sumatera Barat tahun 2015 sebesar 47,60 persen. UNDP (2013) menggambarkan kondisi demografi di suatu daerah yang akan mengalami periode bonus demografi apabila proporsi penduduk muda kurang dari 30 persen sehingga dilihat dari komponen fertilitas, Sumatera Barat tidak dapat memasuki fase bonus demografi.

Tingginya tingkat fertilitas di Sumatera Barat yang mengakibatkan semakin bertambah banyaknya jumlah penduduk muda diperparah dengan penduduk umur produktif yang melakukan migrasi keluar daerah sehingga dependency ratio total penduduk masih berada di atas 50 per 100 penduduk produktif.

\section{Migrasi Penduduk}

Migrasi penduduk merupakan komponen demografi yang memberikan pengaruh lebih cepat pada proses dinamika penduduk dibandingkan dengan mortalitas dan fertilitas. Parameter migrasi yang digunakan adalah migrasi risen karena mencerminkan pergerakan spasial penduduk yang lebih dinamis dan terbaru. Pada Gambar 5 dapat dilihat tren migrasi neto risen penduduk Sumatera Barat.

Gambar 5 memperlihatkan data migrasi penduduk Sumatera Barat berada pada angka minus (-) di setiap periodenya. Angka minus ini dapat diartikan bahwa penduduk yang keluar provinsi lebih banyak dibandingkan dengan penduduk yang masuk ke dalam Provinsi Sumatera Barat. Gambar 5 menunjukkan tren migrasi penduduk Sumatera Barat dari tahun 1980 hingga tahun 2015 berfluktuasi. Pada periode 1980 hingga 1995 grafik mengalami penurunan secara terus menerus dari 60.122 
Ketidaktercapaian Bonus Demografi:

Pembelajaran dari Sumatera Barat

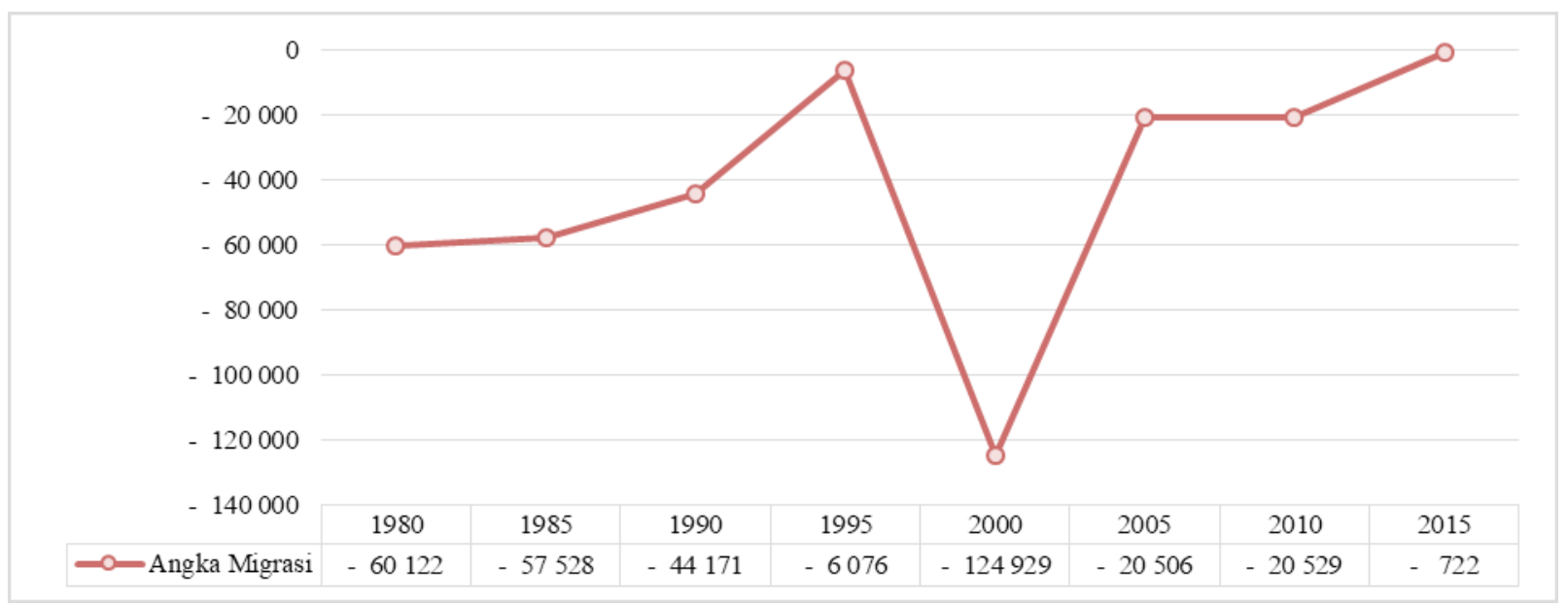

Sumber: Diolah berdasarkan data Sensus Penduduk (1980, 1990, 2000, 2010) dan SUPAS $(1985,1995,2005,2015)$

Gambar 5 Tren Migrasi Neto Risen Penduduk Sumatera Barat Tahun 1980-2015

pada tahun 1980 menurun ke angka 57.528 tahun 1985 lalu turun ke angka 44.741 tahun 1990, dan penurunan drastis terjadi tahun 1995, yaitu menjadi 6.076 per 1.000 penduduk.

Migrasi neto risen tahun 1995 mengalami penurunan karena besarnya jumlah migran masuk ke Sumatera Barat hampir berimbang dengan penduduk yang bermigrasi keluar provinsi Sumatera Barat. Diketahui pada tahun 1995 jumlah migran risen yang masuk ke Sumatera Barat sebesar 138.531, sedangkan penduduk yang bermigrasi keluar Sumatera Barat berjumlah 144.607. Jumlah migran yang masuk ke Sumatera Barat tersebut mengalami peningkatan sebesar 7,35 persen dari jumlah migran masuk tahun 1995. Meningkatnya jumlah migran yang masuk merupakan hal yang wajar karena Sumatera merupakan pulau kedua sebagai daerah tujuan para migran internal di Indonesia setelah Pulau Jawa.

Studi yang dilakukan oleh Leni (2016) mengungkapkan bahwa arus migrasi risen masih menunjukkan pola yang relatif sama, yaitu terkonsentrasi di wilayah barat dan tengah Indonesia periode 1971 hingga 2010. Nugroho dan Pitoyo (2017) juga menambahkan bahwa meningkatnya migran yang masuk disebabkan oleh adanya daya tarik tersendiri bagi migran yang berasal dari daerah lain, terutama terkait dengan pertumbuhan ekonomi di daerah tersebut.

Pada tahun 2000 terjadi peningkatan tajam, yaitu migrasi neto yang sebelumnya berada di angka 6.076 bertambah menjadi 124.929. Hal ini disebabkan oleh adanya dampak dari krisis moneter pada akhir orde Baru, yaitu tahun 1998. Pitoyo (1999) menuturkan bahwa saat itu terjadi kenaikan harga barang sehingga masyarakat cenderung berpikir pragmatis dalam memenuhi kebutuhan sehari-hari. Sektor informal, seperti pedagang kaki lima, menjadi alternatif utama agar masyarakat tetap dapat bertahan hidup. Masyarakat memilih sektor informal, seperti pedagang kaki lima, mengingat toko-toko besar dan supermarket menawarkan harga yang lebih tinggi. Oleh karena itu, masyarakat di 
daerah-daerah memanfaatkan momentum tersebut untuk beralih ke mata pencaharian yang bergerak di sektor informal dan pindah menuju kota-kota besar.

Selain itu, penyebab peningkatan migrasi keluar tahun 2000 adalah meningkatnya pengangguran karena PHK sehingga sektor informal menjadi peluang satu-satunya yang dapat menyelamatkan kelangsungan hidup masyarakat. Sektor informal pada masa itu berperan sangat strategis sebagai katup pengaman pengangguran (Winarso dan Budi, 2013), bahkan mampu menyerap tenaga kerja selama masa pemulihan ekonomi di Indonesia periode 1998-2002 (Firnandy, 2008).

Pada tahun 2005 angka migrasi neto risen mengalami penurunan drastis menjadi 20.506. Penurunan ini terus terjadi hingga tahun 2015, bahkan mencapai angka yang sangat rendah dibandingkan dengan periodeperiode sebelumnya, yaitu 722 per 1.000 penduduk. Angka migrasi neto risen yang mengalami penurunan dapat menjadi indikasi bahwa Sumatera Barat telah menjadi salah satu tujuan migran yang berasal dari provinsi lainnya. Hal ini disebabkan oleh infrastruktur ekonomi dan pendidikan yang selama ini menjadi faktor pendorong penduduk untuk migrasi keluar provinsi telah mengalami banyak perbaikan (BPS, 2015). Kondisi tersebut dapat dibuktikan dengan data provinsi dengan tren migrasi risen neto negatif tertinggi di Indonesia. Posisi Sumatera Barat mengalami penurunan dari urutan kelima tahun 1980 menjadi urutan ketujuh tahun 2010 (Nugroho dan Pitoyo, 2017).

Analisis yang dilakukan terhadap migrasi penduduk Sumatera Barat memberikan suatu kesimpulan bahwa secara keseluruhan, Sumatera Barat termasuk ke dalam provinsi yang konsisten sebagai pengirim migran, baik itu migran seumur hidup maupun migran risen. Oleh karena itu, pengaruh migrasi terhadap jumlah penduduk di Sumatera Barat adalah tidak bertambahnya secara signifikannya proporsi penduduk usia produktif. Sebagaimana yang dijelaskan Mantra (2013), banyak penduduk Sumatera Barat melakukan migrasi ke luar provinsi sehingga memengaruhi piramida penduduk di sekitar kelompok umur dewasa (penduduk umur produktif). Kondisi ini dilatarbelakangi secara kuat oleh adanya tradisi merantau masyarakat Sumatera Barat yang berasal dari suku Minangkabau.

Merantau pada mulanya merupakan dampak dari struktur sosial yang fungsional dalam adat Minangkabau (Naim, 2013). Adapun tujuan merantau disebabkan oleh beberapa hal berikut.

a. Faktor budaya, yaitu tradisi orang Minangkabau akibat dari kedudukan dan struktur sosial laki-laki dalam masyarakat. Laki-laki Minangkabau mengalami dilema karena di rumah istri hanya dianggap sebagai tamu (sumando) yang dihormati, tetapi tanpa hak dan kekuasaan. Sementara itu, di rumah ibu (orang tua lakilaki), suami tersebut didudukkan sebagai mamak dan pengawal keluarga tanpa hak untuk menikmati hasil sawah ladang yang dapat dibawa ke rumah istrinya. Anak lakilaki juga didorong untuk meninggalkan rumah sejak muda. Di rumah, anak lakilaki tidak diperlakukan sama seperti anak perempuan. Anak laki-laki tidur di surau dan belajar mempersiapkan diri untuk menghadapi kehidupan yang sukar di kemudian hari. Dorongan merantau dipersiapkan secara berangsur-angsur sejak muda. Adanya tuntutan adat sebagaimana dalam pepatah adat Karatau madang di hulu, babuah babungo balun, marantau bujang dahulu, di kampuang paguno alun. Pepatah tersebut dimaknai bahwa remaja laki-laki di Minangkabau, 
terutama yang belum menikah, tidak mempunyai peranan apapun dalam adat karena dianggap belum berpengalaman sehingga dianjurkan untuk merantau terlebih dulu agar dapat bermanfaat di masyarakat nantinya.

b. Faktor geografi, yaitu kondisi alam Minangkabau dengan tanah yang subur karena terletak di sepanjang Bukit Barisan cocok digunakan untuk lahan pertanian dan hampir seluruh masyarakat menyibukkan diri dengan kegiatan pertanian. Hanya di Kota Padang dan beberapa kota lainnya di Sumatera Barat yang penduduknya bekerja di sektor nonpertanian, seperti berdagang dan beberapa perkantoran. Orang-orang pedalaman Minangkabau (perdesaan Sumatera Barat) membawa hasil pertanian ke kota-kota di Sumatera Barat, bahkan ke luar provinsi. Keadaan ini yang menciptakan situasi bahwa dunia luar tidak mendatangi Minangkabau, tetapi orang Minangkabaulah yang harus pergi ke dunia luar.

c. Faktor ekonomi, yaitu faktor yang dianggap sebagai muara dari faktor budaya dan geografis tadinya. Hal ini disebabkan oleh budaya yang melatarbelakangi seseorang untuk merantau serta didukung oleh faktor alam dan langgengnya penghargaan yang diberikan orang sekitar terhadap perantau yang bekerja sebagai pedagang, terlebih lagi apabila orang tersebut sukses di rantau.

d. Faktor pendidikan, yaitu anak laki-laki dianjurkan keluar dari rumah dan tidur di mesjid untuk menuntut ilmu agama pada zaman dulunya. Kemudian hal itu berkembang tidak hanya untuk ilmu agama saja, tetapi berbagai ilmu pengetahuan. Namun, hanya terbatas pada anak-anak pembesar setempat, pegawai negeri yang terhormat, ataupun pedagang kaya yang ingin meningkatkan pendidikan anaknya ke tingkat yang lebih tinggi. Perkembangan terkini menunjukkan bahwa pendidikan telah dapat dinikmati oleh seluruh lapisan masyarakat. Sebagian konsep asal dari merantau itu adalah mencari ilmu dan pengalaman untuk mempersiapkan diri agar dapat hidup berguna di kampung sesudah kembali dari rantau. Tempat menimba itu dalam bahasa Sansekerta dilafazkan sebagai 'rantau'.

Menurut Taher (2005), penduduk Sumatera Barat yang berada di rantau (daerah tujuan migrasi) mencapai 70 persen. Hal ini mengingat bahwa penduduk yang bermigrasi tersebut tidak kembali, bahkan banyak dari para migran yang memanggil kerabat lainnya untuk merantau. Namun, perkembangan merantau saat ini cenderung dilatarbelakangi oleh tuntutan kehidupan yang tidak lagi dapat terpenuhi jika hanya berada di kampung halaman. Berbeda dari tujuan dasar merantau pada zaman dulunya yang merupakan ritme de passage, yaitu sebagai sebuah ritual kehidupan (Naim, 2015). Hal ini tergambar dari kondisi merantau yang ditujukan untuk anak laki-laki sejak muda, berangsur-angsur dari surau, ke kota terdekat, dan daerah yang lebih jauh lagi dengan potensi kehidupan yang lebih menguntungkan. Saat ini nilai merantau kian memudar karena tidak hanya laki-laki, penduduk perempuan pun juga banyak yang merantau. Kondisi tersebut dapat dilihat dari proporsi penduduk laki-laki dan perempuan di piramida penduduk Sumatera Barat pada Gambar 1 yang menunjukkan tidak terlalu besar perbedaan di antara kedua jenis kelamin tersebut. Pada awalnya kelompok perantau perempuan dilatarbelakangi oleh alasan ikut suami atau orang tua, tetapi saat ini telah berkembang dengan adanya dorongan untuk meningkatkan pendidikan dan kehidupan (Noveria, 2011). 
Di sisi lain, migrasi penduduk Sumatera Barat yang selalu menunjukkan angka minus telah menyebabkan adanya pengurangan penduduk usia produktif di setiap periodenya. Piramida penduduk dari tahun 1971 sampai tahun 2015 memang menunjukkan adanya pembengkakan pada kelompok penduduk usia produktif, tetapi pertambahan tersebut tidak signifikan (lihat Gambar 1). Sebagai contoh, proporsi penduduk umur 10-14 tahun 1990 mengalami pengurangan tahun 2000 (dapat dilihat di kelompok 20-24 tahun 2000) dan pengurangan ini juga terjadi pada dekade berikutnya.

Berdasarkan proyeksi dependency ratio tahun 2010-2035 oleh BPS dan asumsi dari Kominfo (2014), Sumatera Barat tidak akan meraih bonus demografi karena fenomena migrasikeluaryang dilatarbelakangioleh tradisi merantau. Data migrasi neto menunjukkan bahwa jumlah migran keluar selalu melebihi migran masuk sehingga menghasilkan angka migrasi neto yang konsisten minus di setiap periode. Banyaknya penduduk produktif yang bermigrasi keluar daerah menyebabkan proporsi penduduk produktif tidak mengalami penambahan yang signifikan.

Deskripsinya adalah banyaknya penduduk muda/belum produktif (0-14 tahun) yang harus ditanggung tidak diimbangi dengan peningkatan penduduk produktif (15-64 tahun). Akibatnya, dependency ratio Sumatera Barat masih tinggi (>50 per 100 penduduk produktif). Kondisi kependudukan yang tidak menguntungkan tersebut menyebabkan Sumatera Barat tidak dapat meraih bonus demografi.

\section{Kesimpulan}

Proses demografi yang berlangsung telah menyebabkan Sumatera Barat tidak dapat meraih bonus demografi. Tingkat fertilitas yang masih tinggi, bahkan masih berada di atas TFR nasional serta banyaknya jumlah perempuan usia subur dari kohor baby boom turut berkontribusi menambah jumlah penduduk usia muda. Sementara itu, tren migrasi penduduk selalu menunjukkan angka minus di setiap periode sehingga penduduk usia produktif di Sumatera Barat tidak mengalami penambahan yang signifikan. Kedua komponen tersebut menyebabkan dependency ratio penduduk Sumatera Barat masih berada di atas angka 50 sehingga tidak dapat mencapai fase bonus demografi kurun waktu 2010-2035.

\section{Daftar Pustaka}

Alfana, M. A. F., Hanif, W. A. N. P., dan Iffani, M. 2015. "Mortalitas di Indonesia: Sejarah Masa Lalu dan Proyeksi ke Depan". Naskah pada Seminar Nasional dan PIT IGI XVIII, Jakarta.

Ananta, A. 1997. "Peran Analisis Demografi dalam Perencanaan Pembangunan Ekonomi di Indonesia", dalam Pembangunan Nasional: Teori, Kebijakan, dan Pelaksanaan, diedit oleh Anwar, M. A. Jakarta: FE UI.

Asmanedi dan Wiyono, N. H. 2007. "Struktur dan Persebaran Penduduk". Bahan Presentasi Training Dasar-dasarDemografi Angkatan I. Jakarta.

Bloom, D. E., Canning, D., dan Rosenberg, L. 2011. "Demographic Change and Economic Growth in South Asia", PGDA Working Paper, (67), HIm. 1-21.

Bloom, D. E. dan Canning, D. 2011. "Demographic and Development Policy”, PGDA Working Paper, (66), hlm. 1-6.

Dinas Kesehatan Sumatera Barat. 2014. Profil Kesehatan 2014 Provinsi Sumatera Barat. Padang: Sumatera Barat. 
Firnandy. 2008. "Studi Profil Pekerja di Sektor Informal dan Arah Kebijakan ke Depan". https://www.bappenas.go.id/. Diakses pada 25 Februari 2018.

Hatmadji, S, H., Adioetomo, S. M., Toersilaningsih, R., Wisana, ID. G. K. 2010. "Fertilitas" dalam Dasar-dasar Demografi Edisi 2, diedit oleh Adioetomo, S. M. dan Samosir, O. B. Jakarta: Salemba Empat. Iskarni, P. 2012. "Fertilitas Provinsi Sumatera Barat: Analisis Data Sensus Tahun 2012", Laporan Penelitian, Padang: PSKLH dan BKKBN.

Kementerian Komunikasi dan Informatika. 2014. Siapa Mau Bonus? Peluang Demografi Indonesia. Jakarta: Kominfo.

Latif, A. 1985. "Pengaruh Pendidikan Wanita terhadap Fertilitas di Perdesaan Sumatera Barat". Tesis. UGM.

Leni, H. 2016. "Analisis Mobilitas Penduduk Indonesia berdasarkan Data Sensus Penduduk 1971-2010". Tesis. UGM.

Mantra, I. B. 2013. Demografi Umum. Yogyakarta: Pustaka Pelajar.

Martono, N. 2010. Metode Penelitian Kuantitatif. Analisis Isi dan Analisis Data Sekunder. Jakarta: PT. Raja Grafindo Persada.

Naim, M. 2015. "Budaya Merantau Orang Minang". Seminar Merantau.Singapore: Singapore-Minangkabau Association.

- 2013. Merantau Pola Migrasi Suku Minangkabau. Jakarta: PT. Raja Grafindo Persada.

Noveria, M. 2011. Pertumbuhan Penduduk dan Kesejahteraan. Jakarta: LIPI Press.

Nugroho, S. dan Pitoyo, A. J. 2017. "Arus Migrasi Risen di Indonesia Tahun 19802010", Bumi Indonesia, 6 (4), hlm. 1-9.

Nurrizka, R. H. dan Saputra, W. 2013. "Arah dan Strategi Kebijakan Penurunan Angka Kematian Ibu (AKI), Angka Kematian Bayi (AKB), dan Angka Kematian Balita
(AKABA) di Indonesia", Prakarsa Working Papers, 2013 (01), hlm. 1-19.

Pitoyo, A. J. 1999. "Pedagang Kaki Lima Pada Masa Krisis”, Populasi, 10 (2), hlm. 73-97.

Salim, E., Adioetomo, S. M., Nizam., Arifin, A. N., dan Pratama, A. 2015. Dinamika Kependudukan dan Pembangunan Berkelanjutan di Indonesia. Jakarta: UNFPA.

Siswono, E. 2015. Demografi. Yogyakarta: Ombak (IKAPI).

Taher, E. P. 2005. "Rumah Gadang Riwayatmu Kini", dalam Pertumbuhan Penduduk dan Kesejahteraan, diedit oleh Noveria, M.. Jakarta: LIPI Press.

United Nations Children's Fund. 2012. Kesehatan Ibu dan Anak. Jakarta: UNFPA.

United Nations Population Division. 2013. World Population Prospects: The 2003 Revision. New York: United Nations.

Winarso, H. dan Budi, G. 2013. "Sektor Informal yang Terorganisasi: Menata Kota untuk Sektor Informal". http://tataruang. bpn.go.id/bulletin/. Diakses pada 25 Februari 2018.

Wongboonsin, K. dan Phiromswad, P. 2016. "Demographic Dividend, Human Capital, and Poverty Reduction". http://www.un.org/ esa/ Diakses pada 8 Januari 2017. 